\title{
Kampanye Antikorupsi Kaum Muda melalui Media Sosial Twitter
}

\author{
Tawakkal Baharuddin', Salahudin'², Sjafri Sairin ${ }^{3}$, Zuly Qodir $^{4}$, Hasse Jubba ${ }^{5}$ \\ ${ }^{1,3,4,5}$ Program Doktor Ilmu Politik-Politik Islam, Pascasarjana, Universitas Muhammadiyah Yogyakarta \\ Jl. Brawijaya, Kasihan, Bantul, Yogyakarta, 55183, Indonesia \\ ${ }^{2}$ Program Studi Ilmu Pemerintahan, Fakultas Ilmu Sosial dan Politik, \\ Universitas Muhammadiyah Malang \\ Jl. Raya Tlogomas No.246, Malang, Jawa Timur, 65144, Indonesia \\ E-mail: tawakkal.b.pasca18@mail.umy.ac.id ${ }^{1 *}$; salahudinmsi@umm.ac.id²; sjafrisairin@umy.ac.id³; \\ zuliqodir@umy.ac.id ${ }^{4}$; hasse@umy.ac.id ${ }^{5}$ \\ *Corresponding author
}

\begin{abstract}
Young people are still considered an apathetic group in various countries, including Indonesia. This situation is due to the lack of participatory space to accommodate the interests of the Youth. The presence of social media is slowly providing a new space for creative participation for Young People. This study aims to analyze the use of social media Twitter as a medium for creative participation and political expression for young people against corruption in Indonesia. This study uses a quantitative approach with data sources derived from document studies and Twitter social media. Data were collected using the Ncapture for the Nvivo feature. The research analysis was carried out by data coding, content analysis, and data visualization using the Nvivo 12 Plus analytics software. The results of this study explain that social media Twitter influences the collective interest of the Young People in political discourse, especially the issue of corruption. Young people's expressions on Twitter are proven by creative ideas such as memes, captures, captions, quotes, and hashtags. This creativity is a form of political expression that is also capable of influencing and mobilizing other social media users to engage in a common collective interest in fighting corruption. The substance of this research contributes in the form of recommendations for new concepts in campaigning anti-corruption issues in Indonesia by maximizing the use of Twitter social media. Keywords: Creative Participation; Indonesian Corruption; Political Expression; Twitter; Young People
\end{abstract}

\begin{abstract}
Abstrak
Kaum Muda masih dinilai sebagai kelompok yang apatis di berbagai Negara termasuk di Indonesia. Situasi ini dikarenakan kurangnya ruang partisipatif yang mengakomodir kepentingan Kaum Muda. Kehadiran media sosial perlahan memberikan ruang partisipasi kreatif baru bagi Kaum Muda. Penelitian ini bertujuan untuk menganalisis penggunaan media sosial Twitter sebagai media partisipasi kreatif dan ekspresi politik Kaum Muda melawan korupsi di Indonesia. Penelitian ini menggunakan pendekatan kuantitatif dengan sumber data berasal dari studi dokumen dan media sosial Twitter. Data dikumpulkan menggunakan fitur Ncapture for Nvivo. Analisis penelitian dilakukan dengan pengkodean data, analisis konten dan visualisasi data menggunakan Software analytics Nvivo 12 Plus. Hasil penelitian ini menjelaskan bahwa media sosial Twitter memiliki pengaruh pada minat kolektif Kaum Muda pada wacana politik khususnya masalah korupsi. Ekspresi Kaum Muda di Twitter dibuktikan dengan ide kreativitas seperti meme, capture, caption, quote, dan hastag. Kreativitas tersebut merupakan bentuk ekspresi politik yang sekaligus mampu memengaruhi dan memobilisasi pengguna media sosial lainnya untuk ikut terlibat pada minat kolektif bersama melawan korupsi. Substansi penelitian ini memberikan kontribusi berupa rekomendasi kebijakan dalam mengampanyekan isu-isu antikorupsi di Indonesia dengan memaksimalkan penggunaan media sosial Twitter.
\end{abstract} Kata Kunci: Partisipasi Kreatif; Korupsi Indonesia; Ekspresi Politik; Twitter; Kaum Muda 


\section{Pendahuluan}

Kaum Muda termasuk kelompok yang cukup rentan terkena dampak kasus korupsi. Dampak kasus korupsi secara khusus ikut memengaruhi Kaum Muda untuk mendapatkan jaminan kerja, merusak persaingan, merusak sumber daya, dan kepercayaan sosial (Murimi, 2018; Urien, 2012). Hal ini dapat dilihat dari ketidakefisienan dan meningkatnya biaya karena perilaku korupsi. Korupsi juga ikut menghambat Kaum Muda dalam kehidupan sosial dan politik (Murimi, 2018). Berdasar pada situasi tersebut, maka harapan, otimisme dan idealisme dari Kaum Muda menjadi hal yang sangat dibutuhkan saat ini di dalam upaya memerangi korupsi.

Korupsi memiliki pengertian yang cukup beragam, namun demikian terdapat definisi klasik yang relatif cukup populer pada periode tahun 1990-an, yang menggambarkan korupsi sebagai bentuk dari penyalahgunaan kekuasaan dan juga penyalahgunaan kepercayaan publik demi kepentingan pribadi (Pope, 2000). Beberapa aspek yang mendasari perilaku dan tindakan korupsi tersebut dapat terjadi, seperti munculnya perilaku-perilaku nepotisme dan klientelisme yang juga ditandai dengan adanya keberpihakan seseorang atau kelompok yang saling berinteraksi dan saling berhubungan antara satu dengan yang lainnya (Hangi, 2018; Dávid-Barrett \& Fazekas, 2020). Praktik korupsi saat ini terus menjadi masalah besar di berbagai Negara termasuk di Indonesia (Kuncoro, 2002; Patra, 2018). Tercatat beberapa kasus korupsi yang memiliki nilai kerugian terbesar dalam sejarah Indonesia, yakni kasus Jiwasraya, Asabri, Bank Century, Pelindo II, Kotawaringin Timur, BLBI, E-KTP dan kasus Hambalang (Dzulfaroh, 2020; Sari, 2020; Pujiyono \& Riyanta, 2020). Dampak yang ditimbulkan dari perilaku atau kasus korupsi tersebutdiantaranya, stabilitaskeuangannasional, laju pertumbuhan ekonomi dan kemiskinan (Patra, 2018; Setiadi, 2018; Lutfi et al., 2020).
Kesadaran dan partisipasi dalam memerangi korupsi di Indonesia harus didukung dari banyak pihak, termasuk Kaum Muda yang dinilai masih cukup apatis. Kaum Muda masih digambarkan sebagai golongan yang apatis terhadap isu-isu politik selama beberapa tahun terakhir (Dahl et al., 2018). Seiring dengan perkembangan zaman, golongan Kaum Muda perlahan bangkit melalui karya kreatif dan inovatif. Kebangkitan Kaum Muda juga ditandai dengan ikut terlibat menyuarakan kritik, ide dan gagasan terhadap isu-isu politik, yang khusus kaitannya dengan masalah korupsi. Keterlibatan Kaum Muda dalam mengekspresikan minat pada wacana politik dilakukan dan dimuat dalam berbagai bentuk ide kreativitas yang beragam seperti musik, graffiti, tulisan, poster yang disebar di beberapa jejaring media sosial (Saroh, 2016; Keating \& Melis, 2017; Kligler-Vilenchik \& Literat, 2018).

Kehadiran media sosial tidak lepas dari kajian tentang media baru (New Media). Pada umumnya teori media baru menilai sebuah perubahan terhadap akses pada teknologi yang dilihat dari cara adopsi masyarakat yang terbatas, dan perlahan berubah menjadi pola adopsi secara massal (Livingstone, 1999). Media baru sebagai media di mana semua pesan komunikasi memiliki akses kemudahan yang didistribusikan menggunakan teknologi internet dan melibatkan audiensi atau pengguna untuk meningkatkan proses interaksi dan komunikasi (Hansen, 2004; McQuail, 2011). Dalam konteks tersebut, proses interaksi ikut melibatkan audiensi secara langsung. Audiensi di dalam kajian media baru tidak hanya sebatas viewer, melainkan menjadi pengguna yang aktif.

Hubungan media baru dengan media sosial juga dapat ditelusuri pada kajian terkait jejaring komunikasi (communication network). Jaringan komunikasi dianggap sebagai perantara di dalam sebuah komunitas yang bertujuan untuk memaksimalkan setiap arus informasi (Kossinets et al., 2008). Arus informasi tersebut mengalir dengan bebas, dan memudahkan akses pada 
publik secara luas. Hal tersebut juga perlahan ikut menginisiasi munculnya kesadaran publik dalam memaksimalkan penggunaan media sosial. Media sosial merupakan pendukung di dalam jaringan komunikasi (Susanto, 2017; Sobkowicz et al., 2012; Kim \& Kim, 2017). Jejaring komunikasi, khususnya media sosial telah banyak merubah kebiasaan dan gaya hidup di dalam kehidupan sosial (James et al., 2017; Kertamukti et al., 2019).

Pemanfaatan jejaring media sosial juga dinilai dapat memberi dampak pada proses demokratisasi di banyak Negara termasuk di Indonesia. Hal tersebut banyak didasari pada perkembangan teknologi komunikasi dan informasi yang dianggap semakin memudahkan interaksi antar individu dan kelompok (Susanto, 2017; Hasfi, Usmand \& Santoso, 2017; Syahputra, 2017). Demokratisasi ini dapat berjalan maksimal apabila didukung dengan adanya upaya partisipasi yang aktif dari banyak sektor untuk terus terlibat dalam wacana politik yang khusus kaitannya dengan isu-isu antikorupsi di Indonesia.

Adapun penanganan kasus korupsi di Indonesia perlahan telah menunjukkan perubahan yaitu dengan banyaknya kasus-kasus korupsi yang berhasil diungkap oleh lembaga Komisi Pemberantasan Korupsi (KPK). Hal tersebut juga memberi argumentasi penting bahwa Negara dengan sistem demokrasi cenderung memiliki peluang yang cukup besar untuk melakukan perlawanan terhadap kasuskasus korupsi (Reinikka and Svensson, 2005). Situasi demokratis tersebut juga menjadi jalan bagi Kaum Muda untuk ikut terlibat dan berpartisipasi sebagai kelompok yang rentan untuk terlibat dan mulai menunjukkan ekspresi politiknya terhadap wacana politik antikorupsi.

Berdasarkan uraian-uraian yang dijelaskan, maka diperlukan sebuah platform media sosial untuk meningkatkan keragaman bentuk partisipasi masyarakat terutama Kaum Muda yang lebih partisipatif dalam isu-isu politik. Terdapat beragam literatur atau hasil penelitian yang menjelaskan keterlibatan Kaum Muda dengan Politik. Kaum Muda dan politik banyak dikaji atau dianalisis pada aspek minat, sikap, narasi, kepercayaan, pengetahuan, dan partisipasi di dalam politik (Laughland-Booÿ \& Ghazarian, 2020; Ohme, 2020; Khairullina et al., 2020)Sejalan dengan situasi politik tersebut, banyak Aktivis Muda yang mulai peduli dan mulai mencoba mengekspresikan perbedaan pendapat melalui tindakan dalam menantang sebuah kebijakan (Escobar, 2015). Aktivisme politik Kuam Muda ini juga sangat dipengaruhi oleh gaya kepemimpinan politik dari otoritas pemerintah (Partridge, 2008). Sikap tersebut mendorong tindakan simbolis untuk melakukan mobilisasi politik dan aktivisme dalam berbagai bentuk lainnya termasuk di jejaring sosial online (O'loughlin and Gillespie, 2012; Stitzlein, 2015; Nofrima et al., 2020). Hal tersebut ikut berkontribusi pada Kaum Muda dalam mengekspresikan perbedaan pendapat terhadap masalah lainnya yang berkaitan dengan ekonomi, sosial, politik dan isu-isu kebijakan lainnya (O’brien, Selboe \& Hayward, 2018).

Beberapa hasil penelitian lainnya juga menunjukkan bahwa terdapat hubungan positif antara penggunaan media sosial dengan keterlibatan politik Kaum Muda (Xenos, et al., 2014; Loader, et al., 2016; Frelians \& Perbawaningsih, 2020). Terdapat hubungan yang kuat dan positif antara penggunaan media sosial dengan keterlibatan politik di antara Kaum Muda terkait peran serta wawasan yang dimainkan di dalam platform media sosial. Peran dan wawasan tersebut dapat ditunjukkan dengan pendekatan yang lebih politis (Xenos, Vromen \& Loader, 2014). Penggunaan media sosial oleh Kaum Muda juga dilandasi pada penurunan biaya partisipasi dan adanya efisiensi di dalam jaringan sosial online (Ellison, Steinfield \& Lampe, 2007; Takau, 2020). Biaya yang relatif murah membuat Kaum Muda lebih memilih memaksimalkan peran di jejaring media sosial untuk ikut serta pada proses partisipasi di dalam wacana politik. 
Keterlibatan Kaum Muda dalam memainkan peran di media sosial juga didasari atas sebuah argumen, di mana Kaum Muda dianggap sebagai bagian dari digital native (Hsiao, 2018). Kaum Muda sebagai digital native dicirikan dengan kesamaan era berkembangnya media sosial online yang memengaruhi keterampilan dan preferensi Kaum Muda (Bennett et al., 2008). Kaum Muda sebagai digital native yang mahir menggunakan media sosial juga ikut memengaruhi perkembangan literasi digital melalui praktik digital (Smith et al., 2020). Literasi digital sangat bergantung pada ketersediaan media sosial yang memfasilitasi penggunanya untuk lebih mapan dan mahir dalam mengelola berbagai informasi (Talib, 2018; Young et al., 2018). Berdasar pada uraian tersebut, kehadiran media sosial juga memiliki arti penting bagi Kaum Muda untuk memahami dan merespon setiap wacana sosial politik yang ada.

Sloam (2016) menjelaskan bahwa Kaum Muda menggunakan media sosial untuk ikut terlibat aktif secara politik dengan bebas. Hal ini sebagai bentuk ekspresi Kaum Muda dalam menyikapi permasalahan politik (Loader et al., 2014; Sloam, 2014). Pemanfaatan media sosial sebagai media informasi merupakan cara dalam mendapatkan dukungan publik terhadap ide dan gagasan Kaum Muda (Loader, Vromen \& Xenos, 2016). Penggunaan media sosial ini memiliki keutamaan yaitu memfasilitasi komunikasi dan interaksi tanpa batas ruang dan waktu (Sosiawan, 2020; Sosiawan \& Wibowo, 2019; Arniawati \& Sutrisno, 2015). Media sosial terbukti telah ikut memengaruhi keresahan sosial dan politik di antara populasi yang lebih muda, sehingga potensi media sosial dinilai dapat berkontribusi dalam upaya mendorong tindakan politik yang berkelanjutan (Valenzuela, Arriagada \& Scherman, 2014; Skoric \& Poor, 2013). Hasil penelitian lainnya menyebutkan bahwa, pada dasarnya pandangan Kaum Muda dalam menumbuhkan minat politiknya juga banyak dipengaruhi dari lingkungan di dalam komunitasnya sendiri. Minat serta partisipasi politik tersebut juga terbentuk dan direproduksi di dalam komunitas keluarga. Sosialisasi politik dalam komunitas keluarga sangat berkorelasi pada transisi partisipasi Kaum Muda yang perlahan ikut meniru kehidupan politik orangorang dewasa (Mcfarland \& Thomas, 2006). Penelitian lain ikut menjelaskan bahwa minat politik Kaum Muda juga sangat dipengaruhi oleh pengalaman pada kegiatan organisasi sukarela atau kegiatan ekstrakurikuler di sekolah-sekolah. Hal ini kemudian berimplikasi pada ekspresi, perilaku memilih, partisipasi, kampanye dan organisasi politik (Mcfarland \& Thomas, 2006; Krauss et al., 2020).

Ekspresi dan partisipasi politik tersebut sebagai inti dari sebuah Negara demokrasi, dan ekspresi politik dalam media sosial atau online memiliki implikasi untuk kesehatan demokrasi di mana hal tersebut mampu menciptakan ruang baru dalam mendistribusikan informasi, berita serta wacana politik (Cho et al., 2018; Jubba et al., 2020). Penggunaan media sosial sebagai media yang ikut menginisiasi ekspresi politik telah menambah kajian baru dalam studi politik. Hal tersebut didasari bahwa media sosial memiliki konten-konten komunikasi bersifat massal yang bertemu dalam satu media. Peran yang dimainkan dalam ekspresi sosial politik di jejaring media sosial cenderung memanfaatkan aplikasi seperti Facebook dan Twitter (Velasquez \& Rojas, 2017; Wibowo \& Mirawati, 2013; Puspitasari, 2020; Ratnasari, Sumartias \& Romli, 2020).

Aplikasi Twitter termasuk media populer dilihat dari segi historis dan sosiologis yang berguna dalam aktivitas dan interaksi sosial (Murthy, 2012; Hughes et al., 2012). Twitter dalam interaksi sosial juga memiliki peranan yang dapat mereduksi kesenjangan di dalam komunitas. Hal ini dipengaruhi karena Twitter merupakan platform mikroblog yang ikut memfasilitasi peningkatan interaksi melalui sebaran informasi (Fischer \& Reuber, 2011). 
Interaksi menggunakan saluran media sosial Twitter sangat bergantung pada penggunaan jaringan internet (Passini, 2012). Internet sendiri telah merubah banyak aspek, termasuk dominasinya di ruang-ruang publik yang banyak menggerakkan aktivitas sosial dan politik (Jubba et al., 2020). Pemanfaatan internet dapat digunakan melalui perangkat komputer atau ponsel cerdas (Smartphone). Pada penggunaannya, internet cenderung lebih pupuler digunakan oleh kelompok sosial seperti Kaum Muda dibandingkan dengan kelompok yang lainnya, terutama di dalam aktivisme online (Puspitasari \& Ishii, 2016).

Jejaring media sosial, seperti Twitter, semakin dipandang sebagai media komunikasi pilihan bagi setiapjejaring politik untuk mendapat respon dari masyarakat umum, khususnya Kaum Muda (Loader, Vromen and Xenos, 2016; Oktayusita, Suparno \& Rochayanti, 2020). Respon dan penerimaan Kaum Muda pada isuisu politik dilihat dari tiga posisi, yaitu posisi yang dominan, posisi yang dinegosiasikan, dan posisi oposisi. Posisi dominan dianggap bersifat politik yang baik karena dianggap cukup berhasil dalam mengkritik pemerintah dengan menyajikan realitas masalah yang ada. Posisi negosiasi, Generasi Muda melihat isu yang berisi pesan kritik tanpa solusi, dalam kondisi ini Generasi Muda menolak beberapa simbol seperti simbol profesi dan judul di dalamnya, sementara pada posisi oposisi, Generasi Muda menganggap isu politik tidak cukup relevan (Oktayusita, Suparno \& Rochayanti, 2020).

Berdasar pada penelitian dan uraian sebelumnya, dapat diketahui bahwa Kaum Muda memiliki kecenderungan terhadap media sosial sebagai jalan untuk berekspresi pada setiap wacana atau isu-isu politik. Ketergantungan terhadap media sosial merupakan indikasi tingginya interaksi komunikasi Kaum Muda terhadap isu-isu sosial dan politik di jejaring sosial online. Media sosial kemudian dipilih karena kemampuannya yang memungkinkan Kaum Muda untuk menilai dan bereksperimen terkait minat yang dipilih (Lane, Das \& Hiaeshutter-Rice, 2019). Adapun ekspresi maupun eksperimen tersebut dapat dimaksimalkan dengan menggunakan fitur-fitur atau format yang dapat mendukung setiap interaksi di dalam jejaring media sosial seperti kultwit dan twitwar di aplikasi Twitter. Keberadaan kedua format tersebut sekaligus menunjukkan bagaimana budaya kolektivisme juga dapat bertransformasi di ranah digital seperti media sosial Twitter (Firmansyah et al., 2018).

Kolektivisme pada umumnya dapat dipahami sebagai sandingan atau bagian dari perasaan, keyakinan, niat, dan perilaku yang selaras dengan nilai-nilai solidaritas, kepedulian serta kepekaan yang ditunjukkan di dalam komunitas sosial (Hui, 1988). Lebih lanjut, kolektivisme tersebut tidak ditunjukkan hanya di ruang publik atau di tempat-tempat umum saja, melainkan ikut bertransformasi. Seiring dengan massifnya penggunaan aplikasi media sosial, bentuk kolektivisme tersebut kemudian berubah secara online di dalam budaya yang jauh lebih berbeda (Holmes, Balnaves, \& Wang, 2015; Na, Kosinski, \& Stillwell, 2015). Berdasar pada penjelasan tersebut, diketahui bahwa media sosial juga telah memengaruhi munculnya ruang partisipatif bagi komunitas sosial dalam membentuk budaya kolektivisme pada setiap wacana sosial politik tertentu.

Penelitian ini didasari bahwa Kaum Muda memiliki kesempatan yang sama untuk menunjukkan eksistensi dalam bentuk ekspresi di jejaring sosial seperti Twitter. Hal lain yang mendasari penelitian ini juga karena peran media sosial dinilai sebagai ruang yang mampu menginisiasi munculnya ekspresi sosial politik, dan memiliki pengaruh besar terhadap pola partisipasi yang lebih kreatif secara politis (Gil de Zúñiga, Molyneux \& Zheng, 2014). Pemanfaatan media sosial secara masif juga memperoleh efek yang dapat diterima secara masif pula (El Adawiyah et al., 2020; Jubba et al., 2020). 
Penelitian ini cukup berbeda dengan penelitian terdahulu di mana belum banyak dilakukan penelitian yang berkaitan dengan Kaum Muda dalam kaitannya dengan isu-isu politik, yang khusus kaitannya dengan wacana korupsi di Indonesia. Dalam mendukung upaya tersebut, penelitian ini mencoba mengeksplorasi serta mengelaborasi penggunaan media sosial Twitter oleh Kaum Muda terkait kasus korupsi di Indonesia, dengan pendekatan analisis data menggunakan software Nvivo 12 Plus. Hal ini lebih lanjut dijelaskan pada bagian metodelogi penelitian. Penelitian ini juga tidak hanya ingin menjelaskan aspek Twitter sebagai media interaksi sosial politik, tetapi juga sebagai media partisipasi kreatif atau media ekspresi yang dapat dimanfaatkan oleh kelompok-kelompok yang rentan seperti Kaum Muda dalam mengikuti wacana politik yang ada. Tujuan penelitian ini dilakukan untuk menganalisis serta mendeskripsikan bagaimana Kaum Muda memanfaatkan media sosial Twitter dalam mengekspresikan minat kolektif pada kasus korupsi di Indonesia.

\section{Metode Penelitian}

Penelitian ini menggunakan metode kuantitatif dengan analisis isi deskriptif. Subjek penelitian adalah para pengguna media sosial Twitter termasuk akun@kpk_ri. Objek penelitian dilihat dari keterlibatan Kaum Muda dalam menyalurkan ide kreativitas dan ekspresi dalam wacana politik antikorupsi di media sosial Twitter. Sumber data berasal dari studi dokumen dan media sosial Twitter terkait dengan topik serta isu-isu seputar korupsi di Indonesia. Data yang diperoleh di media sosial Twitter dipilih berdasarkan Twitter Search dengan fokus pencarian pada Hastag (\#), berupa \#korupsi, \#korupsiindonesia dan informasi-informasi terkait lainnya. Data yang dipilih tersebut memungkinkan untuk dapat ditelusuri dan dianalisislebihlanjut.Data-datatersebutkemudian dikumpulkan menggunakan fitur Ncapture for Nvivo yang terdapat di Google Chrome.
Data yang berhasil dikumpulkan tersebut, kemudian dipindahkan ke alat analisis yaitu Software Nvivo 12 Plus. Penggunaan Software Nvivo 12 Plus dalam penelitian ini dipilih karena software tersebut ikut menyediakan ruang bagi peneliti untuk menyimpan data, mengelola data, menganalisis dan memaksimalkan tahapan visualisasi data (Phillips and $\mathrm{Lu}$, 2018). Penggunaan Nvivo 12 Plus juga sudah terbukti dapat dimanfaatkan dalam menganalisis penelitianseputarkorupsidiIndonesia(Salahudin, Nurmandi, \& Loilatu, 2020). Lebih lanjut, data yang dikumpulkan di Software Nvivo 12 Plus, selanjutnya dilakukan pengklasifikasian pada data dan dikoding berdasarkan Text Search Query, Word Frequency Query, dan Sentiment Analysis.

Kueri pencarian teks (Text Search Query), memungkinkan peneliti mencari kata atau frasa yang sering diungkapkan atau digunakan secara lebih luas di Twitter terkait isu-isu korupsi di Indonesia. Kueri frekuensi kata (Word Frequency Query), untuk mencantumkan kata yang paling sering muncul atau kata-kata yang paling umum digunakan, sedangkan Sentiment Analysis berguna untuk mengidentifikasi ekspresi sentimen terkait kasus korupsi. Hasil pengkodean pada data tersebut dilanjutkan dengan tahapan visualisasi berupa grafik dan tabel. Data tersebut kemudian didiskripsikan dan dianalisis. Teknik analisis data menggunakan pendekatan kuantitatif dengan analisis isi deskriptif yang dilakukan dengan menilai keterlibatan Kaum Muda di dalam jejaring Twitter terhadap wacana politik terkait kasus korupsi di Indonesia.

\section{Hasil Penelitian dan Pembahasan \\ Pemetaan Kasus Korupsi di Twitter: Wacana Politik Kaum Muda}

Pada wacana politiknya, Kaum Muda banyak dipengaruhi oleh sebaran informasi yang terdapat di jejaring media sosial seperti Twitter. Kaum Muda memanfaatkan jejaring sosial online berupa media sosial Twitter sebagai media komunikasi dan informasi untuk ikut terlibat 


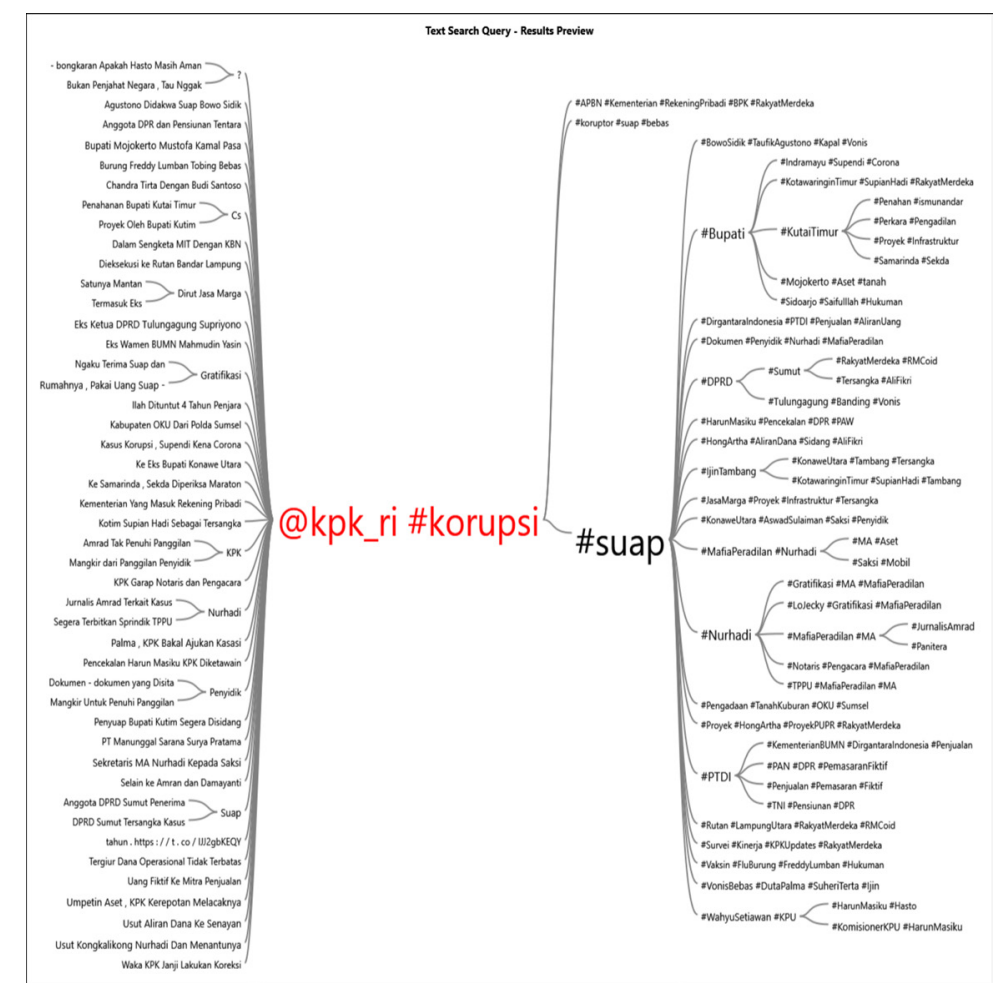

Gambar 1. Pemetaan Kasus Korupsi di Twitter

Sumber: Diolah peneliti menggunakan NVivo12 Plus (2020)

pada wacana politik yang berkembang. Ekspresi politik Kaum Muda ini juga sangat ditentukan oleh situasi politik termasuk pada isu-isu korupsi di Indonesia. Terdapat beberapa kasus korupsi di Indonesia yang pada mulanya disebarkan oleh masyarakat umum lainnya di platform media sosial, dan hal tersebut ikut berdampak pada Kaum Muda untuk memberikan respon politiknya.

Pemetaan kasus korupsi di Indonesia sangat erat kaitan dan pengaruhnya dalam pola partisipasi masyarakat umum termasuk Kaum Muda. Pemetaan tersebut meliputi wacana antikorupsi, kritik dan permasalahan lainnya yang masih terkait seputar kasus korupsi di Indonesia. Pemetaan ini diperoleh dari berbagai sumber yang tersebar di dalam jejaring sosial online seperti portal berita dan media sosial.

Gambar 1 merupakan sebaran informasi yang tersebar di jejaring media sosial Twitter terkait isu dan kasus-kasus korupsi, yang ikut memengaruhi wacana politik antikorupsi Kaum
Muda di Indonesia. Pemetaan kasus korupsi tersebut juga merupakan bagian dari tumbuhnya minat Kaum Muda dalam memahami pesan dan informasi terkait korupsi yang tersebar di media sosial Twitter. Situasi tersebut membuat Kaum Muda belajar untuk menunjukkan sikap partisipatif dengan ikut menyebarkan informasi seputar korupsi di media sosial. Sebaran informasi yang begitu cepat, ditambah dengan kebiasaan Kaum Muda memainkan aplikasi media sosial Twitter juga ikut memengaruhi wacana politik antikorupsi menjadi lebih cepat tersebar. Sebaran informasi di media sosial tersebut merupakan indikasi bahwa Kaum Muda tidak lagi tertutup untuk ikut memberikan respon terhadap isu-isu korupsi di Indonesia. Wacana korupsi yang tersebar di Twitter juga merupakan bagian dari tumbuhnya kesadaran dan minat Kaum Muda pada wacana antikorupsi. 
Sentiment Result: Korupsi Indonesia (Twitter)

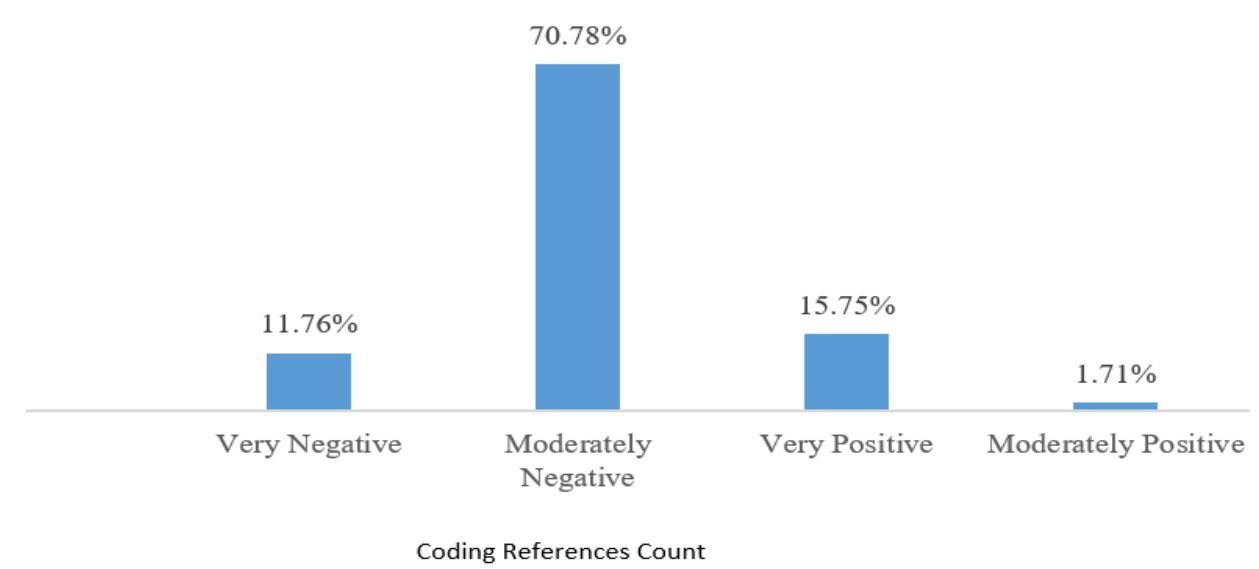

Gambar 2. Sentimen Publik di Twitter Terkait Kasus Korupsi dan Penegakan Hukum Sumber: Diolah peneliti menggunakan NVivo12 Plus (2020)

Kaum Muda memainkan peran yang relatif cukup penting sebagai "motor penggerak", yang berfungsi untuk memberikan komentar, sentimen dan menyebarluaskan segala informasi-informasi terkait kasus korupsi. Aktivisme politik Kaum Muda di media sosial Twitter juga ikut merubah pola edukasi tentang gerakan antikorupsi yang selama ini terkesan kaku dan konservatif. Kehadiran media sosial Twitter terbukti berhasil memberikan ruang politik baru bagi Generasi Muda. Informasi terkait kasus korupsi di Indonesia juga terbukti sangat mudah di akses oleh siapa saja, termasuk oleh Kaum Muda. Informasi tersebut juga ikut memengaruhi persepsi Kaum Muda untuk terlibat dan mengakomodir kepentingan melalui aktivisme di ruang digital. Aktivisme ditunjukkan dengan pendekatan yang relatif dapat dimengerti oleh pengguna media sosial lainnya. Aktivisme tersebut dilakukan dengan memperhatikan budaya digital yang mengakomodasi populasi di dalam ruang digital. Keadaan tersebut cenderung diaplikasikan dengan memaksimalkan fiturfitur atau konten digital lainnya. Hal ini menjadi jalan bagi Kaum Muda untuk terus mengekspresikan minat politiknya di jejaring media sosial, khususnya media sosial Twitter.

\section{Ekspresi Politik Kaum Muda di Twitter Terkait Kasus Korupsi}

Ekspresi politik Kaum Muda mempunyai karakteristik yang berbeda, dilihat dari karakternya yang tumbuh bersamaan dengan munculnya beragam platform media sosial. Hal tersebut menegaskan bahwa perubahan ekspresi politik Kaum Muda juga mengikuti perkembangan teknologi (Wirawan \& Yuliartini, 2018). Kemunculan teknologi internet ini juga ikutmenginisiasi perkembangan media sosial, dan keadaan tersebut kini perlahan ikut melegitimasi aktivisme politik di ruang-ruang digital (Jati, 2016). Keadaan tersebut juga berdampak pada terbukanya peluang bagi Kaum Muda dalam menunjukkan sikap dan ekspresi yang berbeda pada wacana politik yang berkembang, khususnya seputar korupsi di Indonesia.

Ekspresi politik Kaum Muda pada mulanya ditentukan oleh situasi politik di Indonesia, khususnyamasalah penanganan korupsi. Keadaan tersebut berlanjut pada massifnya sebaran informasi di media sosial. Adapun ekspresi dan tindakan politik Kaum Muda juga dipengaruhi oleh faktor penegakan hukum di Indonesia yang dinilai masih belum berjalan dengan maksimal, terutama terkait penanganan kasus korupsi. 


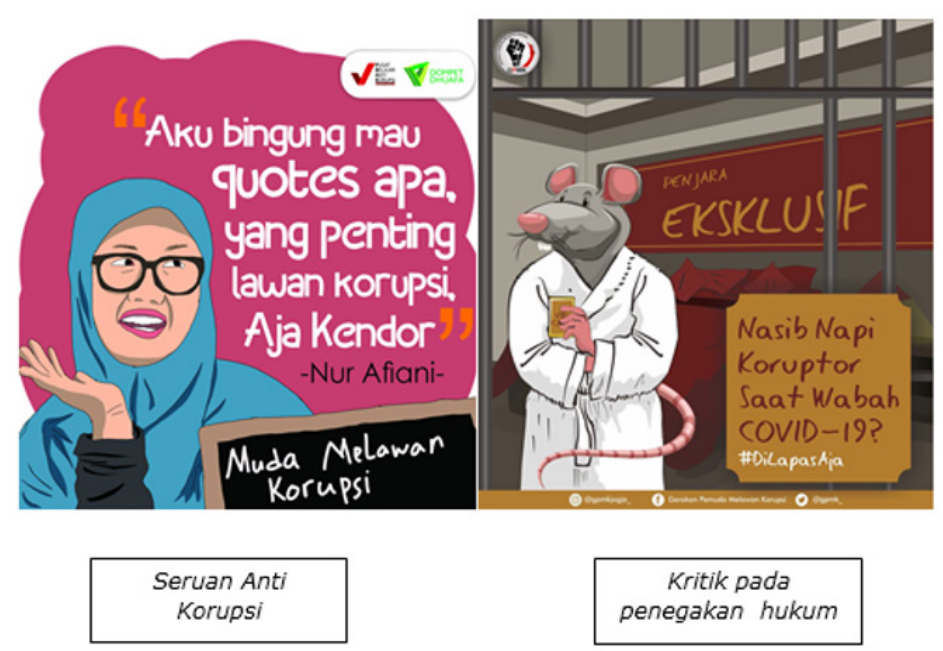

Gambar 3. Meme Terkait Kasus Korupsi

Sumber: Diolah peneliti menggunakan Twitter Search (2020)

Hal ini menjadi sektor yang relatif cukup rentan karena regulasi juga ditentukan oleh otoritas pemerintah yang terkait (Rimšaite, 2019), dan selain itu juga kasus korupsi menjadi isu yang dianggap cukup sensitif karena ikut melibatkan nama-nama besar di dalamnya. Beberapa kasus korupsi tersebut ikut menarik Tokoh Politisi, Swasta dan Pejabat Publik yang cukup populer di masyarakat umum.

Pada situasi tersebut membuat masyarakat umum, khususnya Kaum Muda memilih untuk tetap dan ikut memberikan respon, sikap, dan sentimen terkait upaya penegakan hukum seputar kasus korupsi di Indonesia. Pada Gambar 2 menunjukkan hasil dari sentimen yang dianalisis menggunakan software Nvivo 12 Plus.

Tidak adanya kepercayaan publik membuat kelompok sosial seperti Kaum Muda mulai ikut mengkritik dan berekspresi. Situasi ini akhirnya ikut mendorong Kaum Muda dan komunitas sosial lainnya untuk memberikan reaksi serta ekspresi politik berupa sentimen di berbagai platform media sosial termasuk Twitter. Terdapat berbagai sentimen selama ini terkait kasus korupsi di Indonesia terutama masalah penegakan hukum. Sentimen ini banyak membahas bagaimana upaya dan kinerja dari Komisi Pemberantasan Korupsi (KPK) di Indonesia. Komisi Pemberantasan Korupsi (KPK) merupakan institusi atau Lembaga Negara yang secara khusus dibentuk serta diinisiasikan untuk melakukan pemberantasan tindak pidana korupsi, sebagaimana yang telah diatur dalam UU No. 30 Tahun 2002 (KPK, 2002). Dalam Konsideran UU No. 30 Tahun 2002, juga dijelaskan bahwa pembentukan KPK dikarenakan faktor pemberantasan tindak pidana korupsi yang terjadi di Indonesia masih belum dilaksanakan secara optimal, sedangkan lembaga pemerintah yang menangani perkara tindak pidana korupsi juga dinilai belum berfungsi secara efektif dan efisien.

Hasil sentimen tersebut telah memberikan argumen penting bahwa masyarakat umum termasuk Kaum Muda masih belum cukup puas terhadap kinerja dari Komisi Pemberantasan Korupsi (KPK) di Indonesia. Terlebih lagi, LembagaKPKsecarainternalmasih seringterlibat dalam konflik strukturalnya. Keadaan atau situasi tersebut perlahan membuat Kaum Muda mulai ikut menyuarakan ide dan gagasannya di jejaring sosial online, berdasarkan keadaan dan wacana politik yang berkembang terkait kasus korupsi 


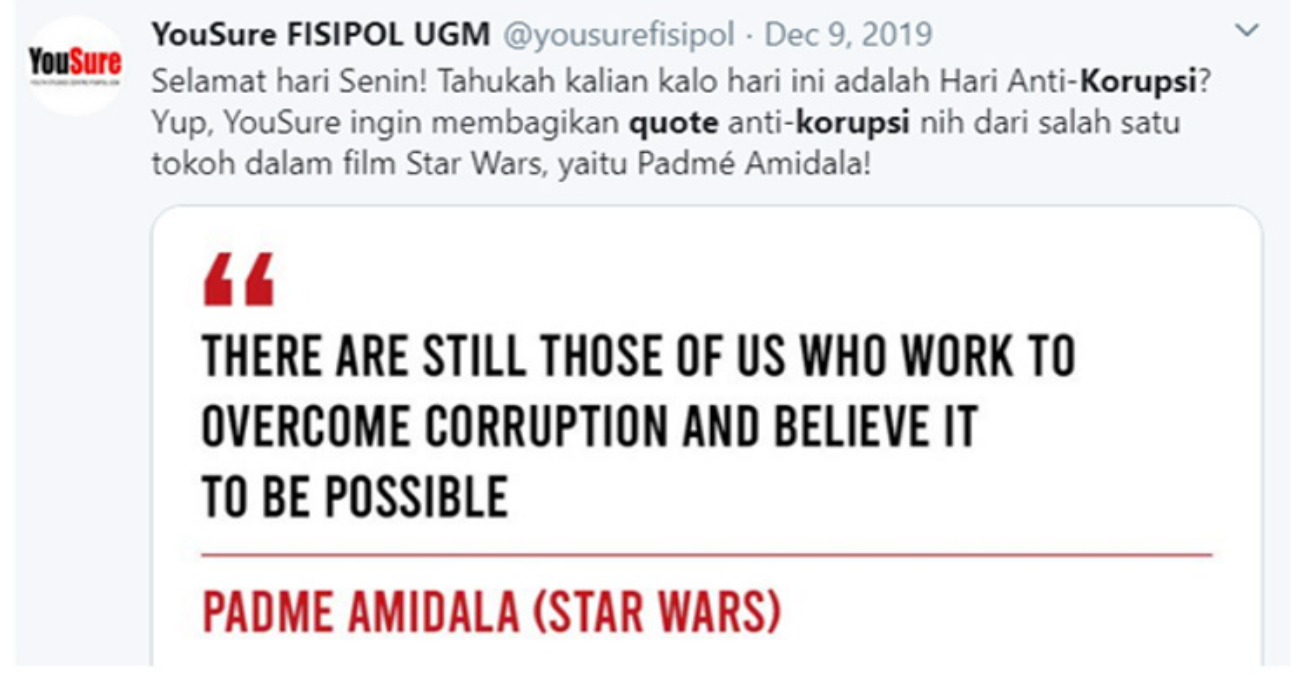

Gambar 4. Caption dan Quote Terkait Kasus Korupsi

Sumber: Diolah peneliti menggunakan Twitter Search (2020)

dan upaya penanganannya di Indonesia. Dalam hal ini, Kaum Muda telah mengambil jalan yang berbeda yaitu dengan semangat partisipasi kreatif yang lebih baru dengan memaksimalkan potensi di jejaring sosial seperti media sosial Twitter.

\section{Kreatifitas Kaum Muda di Twitter Melawan Korupsi}

Media Sosial juga memberikan tempat bagi setiap penggunanya untuk terus berinovasi dan berkreativitas (Ratten, 2017). Kreativitas dalam media sosial ditunjukkan pada perilaku dinamis dengan memperhatikan situasi sosial yang kompleks (Lee et al., 2015; Ratten, 2017). Dalam situasi politik di Indonesia juga memberikan kesempatan bagi Kaum Muda di Twitter untuk ikut merespon setiap informasi atau wacana politik yang berkembang. Respon tersebut dilakukan dengan bentuk partisipasi kreatif di media sosial Twitter. Kaum Muda yang memiliki akses terhadap media sosial Twitter telah memainkan peran yang beragam guna menunjukkan minat dan eksistensinya dengan berbagai macam cara, seperti membuat dan menyebarkan beberapa pesan atau konten kreatif seperti Meme, Caption, Quote dan Hastags.

\section{Gambar Meme}

Meme merupakan metode umum yang digunakan oleh individu untuk berkomunikasi secara online. Pengguna internet sering menggunakan meme untuk saling berkomunikasi di media sosial termasuk media sosial Twitter (Grundlingh, 2018). Konten meme menggabungkan budaya humor dengan relevansi budaya di era digital (Beskow, Kumar \& Carley, 2020). Dalam situasi politik dan isu-isu korupsi di Indonesia, meme juga sering digunakan Kaum Muda untuk memberikan respon politiknya. Konten meme pada Gambar 3 hanya merupakan sampel atau contoh dari banyaknya gambar meme lainnya yang tersebar di jejaring media sosial Twitter. Adapun sampel dari meme tersebut menjelaskan bahwa pentingnya Kaum Muda untuk turut serta dan berkontribusi terhadap isuisu korupsi di Indonesia. Selain itu, terdapat pesan lainnya di mana dalam upaya pemberantasan kasus korupsi juga memerlukan bentuk ketegasan dari otoritas melalui penagakan hukum. Pesan yang ditunjukkan Kaum Muda melalui meme di jejaring media sosial sangat beralasan, karena sejauh ini penanganan kasus korupsi masih belum cukup maksimal, minimal dilihat 
dari aspek ketegasan otoritas dalam menindak dugaan-dugaan kasus korupsi di Indonesia (Putri \& Arifin, 2019). Pesan lainnya juga dinilai bahwa penggunaan meme merupakan alternatif yang ikut memudahkan keterlibatan komunitas sosial lainnya untuk menunjukkan sikap, minat serta ekspresi politiknya di ruang digital. Penggunaan media sosial sebagai harapan agar dapat mengakomodasi munculnya kesadaran Kaum Muda lainnya terhadap ancaman dan bahaya yang ditimbulkan oleh korupsi.

Media sosial menjadi media yang kemudian dilihat sebagai tempat atau wadah dalam upaya menumbuhkan semangat partisipatif Kaum Muda yang selama ini dianggap apatis. Hal ini menjadi argumen penting di mana Kaum Muda juga mampu ikut terlibat dan berpartisipasi dalam upaya melawan segala bentuk dan isu-isu korupsi di Indonesia. Meme kemudian dianggap sebagai media baru yang dimanfaatkan untuk menyampaikan pesan dan kritik melalui konsep kerativitas Kaum Muda di media sosial Twitter. Meme berhasil digunakan untuk tujuan komunikasi karena karakteristik dari meme berbentuk (gambar makro), yang pada dasarnya sangat mudah dipahami oleh pengguna internet atau pengguna jejaring media sosial lainnya (Grundlingh, 2018).

Gambar meme sebagai respon Kaum Muda dalam memaksimalkan penggunaan media sosial Twitter. Pemilihan meme juga digunakan untuk dapat terhubung dengan pengguna media sosial lainnya. Terkait korupsi, meme merupakan model atau alternatif dalam mendistribusikan informasi seputar korupsi. Meme juga sebagai representasi dari ide dan gagasan Kaum Muda yang ditunjukkan dengan konten kreativitas di jejaring media sosial online. Aktivisme dengan penggunaan meme tersebut juga merupakan pendekatan yang relatif ikut memengaruhi minat dan sikap Kaum Muda pada wacana politik tertentu di Indonesia, khususnya korupsi.

\section{Captions dan Quotes}

Selain memanfaatkan meme sebagai bentuk partisipasi kreatif di jejaring media sosial Twitter, Kaum Muda juga menggunakan caption dan quote untuk ikut memberikan pesan terhadap isu-isu korupsi di Indonesia. Caption merupakan keterangan atau deskripsi singkat pada gambar, grafik, foto atau tabel di media sosial (Purbey et al., 2017). Keterangan tersebut dimuat dengan pendekatan pada teks yang menghasilkan berbagai deskripsi berupa keterangan gambar yang informatif (Lu et al., 2018).

Penggunaan Twitter di kalangan umum termasuk Kaum Muda juga memiliki arti penting di mana Twitter lebih memungkinkan penggunanya untuk memainkan kata-kata atau konten yang berbasis pada teks seperti pada Gambar 4. Hal ini juga memberikan perbedaan mendasar pada aplikasi jejaring sosial lainnya seperti Instagram (Pittman \& Reich, 2016). Platform media sosial berbasis pada teks seperti Twitter telah memberikan ruang bagi siapa saja, termasuk Kaum Muda untuk ikut terlibat dalam upaya membangun opini politik melalui aktivisme di jejaring sosial online. Penggunaan teks atau kata menjadi hal dominan bagi Kaum Muda dalam membangun ide kreasinya yang diwujudkan melalui caption dan quote.

Penggunaan caption dan quote pada dasarnya cukup populer digunakan di jejaring media sosial (Guinness, Cutrell, \& Morris, 2018; Sagiyanto \& Ardiyanti, 2018). Caption merujuk pada ungkapan atau penjelasan yang ditulis untuk merepresentasikan isi pesan secara singkat yang terhubung dengan quote. Penggunaan caption dan quote ditampilkan secara bersamaan di media sosial. Hal tersebut sering digunakan oleh pengguna media sosial, termasuk Kaum Muda. Terdapat hubungan antara penggunaan quote dengan Kaum Muda dilihat dari ketertarikannya pada aspek perasaan, situasi, dan minat (Laeli \& Kusumaningrum, 2018). Aspek tersebut memengaruhi Kaum Muda untuk memilih serta menggunakan quote 


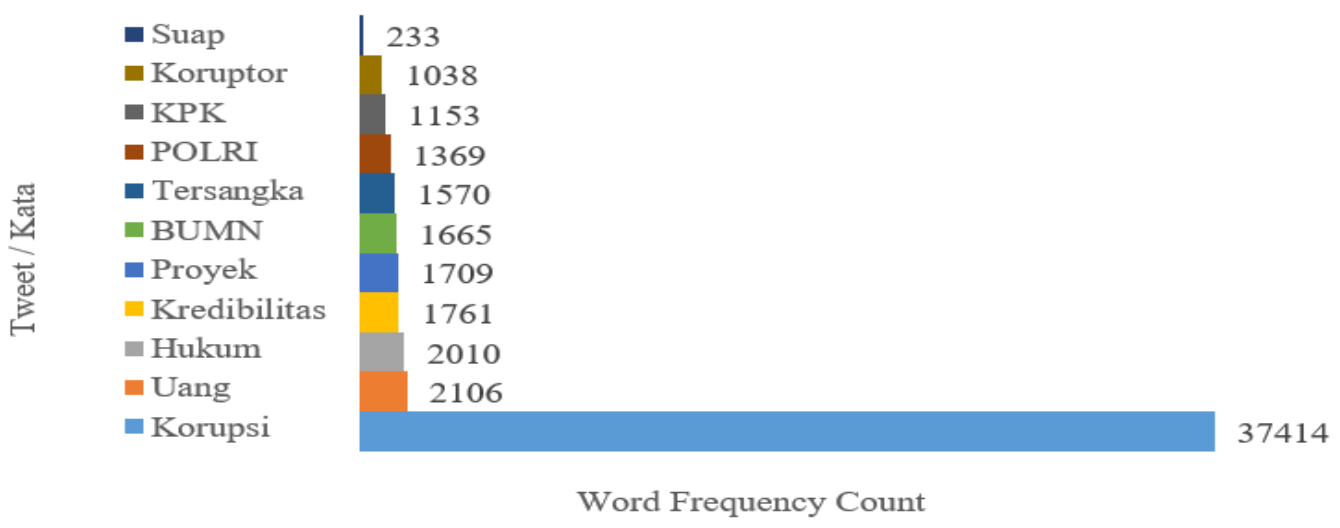

Gambar 5. Jumlah Tweet Berdasarkan Kata

Sumber: Diolah peneliti menggunakan NVivo12 Plus (2020)

dalam menunjukkan perasaan dan sikap di media sosial. Terkait kasus korupsi, quote yang dimanfaatkan Kaum Muda memiliki arti penting untuk melegitimasi ide dan gagasan pada wacana politik tertentu termasuk gerakan antikorupsi.

Keterlibatan Kaum Muda tersebut juga didasari pada setiap isu-isu terkait kasus korupsi yang sebelumnya sudah terlanjur tersebar di beberapa portal berita konvensional atau platform berita online lainnya. Adanya sebaran informasi tersebut membuat Kaum Muda mencoba memaksimalkan fitur yang ada di dalam jejaring sosial Twitter seperti tweet. Terdapat kata atau teks yang banyak di tweet terkait kasus korupsi di Indonesia, yang juga ikut memengaruhi sikap dan gagasan politik Kaum Muda. Data pada Gambar 5 diolah dari hasil pengkodean data Twitter menggunakan Nvivo 12 Plus. Data dianalisis berdasarkan Word Frequency Query. Terdapat tweet yang banyak di bahas yakni tentang korupsi, uang, hukum, kredibilitas, proyek, BUMN, tersangka, POLRI, KPK, Koruptor dan masalah suap. Tweet tersebut merupakan topik bahasan yang paling banyak dibahas di Twitter dan ikut memengaruhi minat keterkibatan Kaum Muda pada informasi terkait kasus korupsi di Indonesia.
Penggunaan tweet berpengaruh pada tingkat sebaran informasi di media sosial Twitter. Tweet tersebut juga ikut memberi dampak pada sebaran konten sehingga memicu pengguna media sosial lainnya untuk terlibat aktif dan berpartisipasi di dalam wacana politik terkait korupsi di Indonesia. Aktivisme tersebut cenderung dapat memobilisasi pengguna media sosial lainnya dan sekaligus ikut memengaruhi minat kolektivitas pada gerakan antikorupsi di Indonesia. Adanya tweet tersebut juga ikut menunjukkan bagaimana budaya kolektivisme mampu bertransformasi di ranah digital (Firmansyah et al., 2018).

\section{Penggunaan Hastags}

Hashtag atau tagar dengan simbol (\#), semakin populer di jejaring media sosial Twitter. Hastag yang digunakan di media sosial memiliki fungsi untuk menyusun konten yang lebih kreatif. Terdapat beberapa motivasi sehingga hastag dapat digunakan di dalam jejaring sosial Twitter yaitu secara fungsional dinilai dapat menghibur, mengatur, mendesain, membangun sebuah tren, mengikat, menginspirasi, meringkas bahasan, dan bersifat mendukung pada setiap wacana (Rauschnabel, Sheldon \& Herzfeldt, 2019). Hashtag juga dapat berfungsi sebagai alat intervensi yang bersifat terorganisir, dan mampu menginisiasi munculnya sebuah perspektif baru (Rentschler, 2017). 
Tabel 1. Jumlah Hastag Terkait Kasus Korupsi

\begin{tabular}{lc}
\hline Hastag & Jumlah Hastag \\
\hline \#KPK & 943 \\
\#Korupsi & 334 \\
\#Suap & 155 \\
\#Bertobatlahrezim & 148 \\
\hline
\end{tabular}

Sumber: Diolah peneliti menggunakan NVivo12 Plus (2020)

Fitur hastag ini juga telah banyak digunakan oleh berbagai kalangan dari pengguna media sosial di Indonesia termasuk Kaum Muda di media sosial Twitter. Penggunaan hastag telah memberi dampak yang cukup penting agar sebaran informasi lebih cepat tersebar. Hastag juga memberikan peluang mobilitas yang tinggi untuk memengaruhi minat dan partisipasi masyarakat umum, khususnya Kaum Muda untuk ikut terlibat di dalam wacana antikorupsi di Twitter. Data jumlah hastag (\#) atau tagar yang sering digunakan di Twitter terkait kasus korupsi di Indonesia yakni \#KPK, \#Korupsi, \#Suap, \#Bertobatlahrezim. Adapun data dari jumlah hastag tersebut dapat dilihat pada Tabel 1.

Hastag dapat memengaruhi setiap penggunanya yang aktif di dalam media sosial Twitter termasuk Kaum Muda. Kaum Muda memiliki keberanian untuk memberikan tanda hastag (\#) pada setiap konten informasi di Twitter terkait kasus korupsi. Kaum Muda memiliki banyak opsi atau pilihan untuk memaksimalkan penggunaan fitur-fitur aplikasi di Twitter, dan ditambah dengan ide kreatifnya sendiri untuk menunjukkan identitas dan eksistensinya pada wacana politik yang berkembang. Twitter dan Kaum Muda memiliki hubungan yang saat ini tidak dapat dipisahkan, terutama minat pada gerakan antikorupsi di Indonesia.

Selama ini gerakan antikorupsi atau upaya pemberantasan korupsi di Indonesia sudah dicoba dengan beragam cara, baik melalui pendidikan formal atau dengan pendekatan di lingkungan keluarga (Montessori, 2012; Widodo, 2019; Rabi'e \& Nurhidayati, 2018). Namun demikian, pendekatan tersebut masih dinilai belum cukup maksimal karena partisipasi yang masih minim dan juga terbatas (Rabi'e \& Nurhidayati, 2018). Hal tersebut juga menunjukkan bahwa di dalam komunitas sosial juga masih terdapat kesenjangan yang cukup serius, terutama di dalam wacana antikorupsi di Indonesia (Pertiwi, 2019). Situasi tersebut kemudian dipandang perlu untuk melakukan pendekatan yang lebih memungkinkan keterlibatan publik untuk ikut terlibat pada wacana antikorupsi, terutama keterlibatan Kaum Muda.

Kehadiran media sosial Twitter perlahan membuka ruang partisipatif baru bagi publik untuk ikut terlibat pada wacana anti korupsi, termasuk Kaum Muda di Indonesia. Hubungan Kaum Muda dengan media sosial dinilai cukup intens, minimal dilihat dari posisinya sebagai digital native. Hubungan tersebut perlahan membuka ruang partisipatif dan kesempatan bagi Kaum Muda untuk mengambil peran dalam upaya membangun narasi antikorupsi secara luas di jejaring sosial online seperti Twitter. Kehadiran media sosial tersebut juga dianggap sebagai peluang munculnya konsep baru dalam memaksimalkan setiap gerakan serta kampanye pada isu-isu terkait korupsi di Indonesia. Pada intinya, media sosial dengan Kaum Muda merupakan kombinasi yang cukup relevan dilihat dari perkembangan teknologi yang semakin canggih dan memadai, khususnya di dalam pemahaman media baru dan jaringan komunikasi. 
Kaum Muda tidak lagi ragu untuk ikut merespon setiap informasi yang tersebar di jejaring sosial online seperti Twitter, bahkan Kaum Muda juga sering menjadi penggerak bagi komunitas sosial lainnya untuk ikut terlibat pada wacana politik seperti isu-isu terkait kasus korupsi melalui ide-ide atau gagasan kreatifnya. Hal ini bahkan dapat memengaruhi metode dan pola pada keterlibatan, partisispasi dan mobilisasi di ruang publik lainnya. Respon politik di media sosial ini dilihat sebagai upaya yang mampu merubah situasi politik menjadi lebih kondusif (Skoric \& Poor, 2013). Situasi tersebut juga menjadi jalan alternatif untuk mendukung proses demokratisasi di Indonesia menjadi lebih terbuka, khusunya bagi kelompok rentan seperti Kaum Muda dalam menunjukkan minat politiknya.

Berdasar pada uraian-uraian di atas, diketahui bahwa penggunaan media sosial, khususnya penggunaan media sosial Twitter sangat berdampak pada tumbuhnya minat dan kesadaran Kaum Muda terhadap wacana politik. Kaum Muda telah mengambil pilihan untuk menunjukkan keresahan terhadap kasuskasus korupsi di Indonesia, dan sekaligus mengambil peran untuk ikut terlibat di dalam gerakan dan kampanye antikorupsi secara kolektif. Kolektivitas tersebut dicirikan dengan pendekatan yang lebih kreatif di jejaring media sosial Twitter. Hal ini juga menunjukkan bahwa Kaum Muda perlahan bangkit dari sikap yang awalnya dianggap apatis menjadi lebih partisipatif. Hubungan media sosial dengan Kaum Muda yang partisipatif tersebut juga dinilai sebagai bagian dari tumbuhnya literasi digital bagi Kaum Muda dalam memahami wacana politik Indonesia. Pada akhirnya, penggunaan media sosial secara positif tersebut, diharapkan ikut berimplikasi pada tumbuhnya kesehatan demokrasi di Indonesia.

\section{Simpulan}

Platform media sosial online seperti Twitter sangat memengaruhi semangat partisipasi dan ekspresi politik Kaum Muda terhadap wacana dan isu-isu politik yang ada di Indonesia. Pemanfaatan media sosial tersebut juga membuktikan bahwa Kaum Muda perlahan bangkit dari sikap yang sebelumnya dinilai apatis menjadi partisipan yang aktif dan kreatif. Aplikasi media sosial Twitter telah memberikan ruang partisipatif baru bagi Kaum Muda untuk ikut terlibat dan berekspresi mengikuti wacana politik yang berkembang, seperti pada isu-isu korupsi di Indonesia. Hasil penelitian ini juga menunjukkan bahwa Kaum Muda dapat memaksimalkan potensi ide serta gagasan kreatifnya.

Ekspresi politik Kaum Muda di media sosial Twitter dibuktikan dengan nilai-nilai kreativitas seperti pembuatan konten informatif berupa meme, capture, caption, quote dan juga hastag. Kreativitas tersebut merupakan bentuk ekspresi politik yang sekaligus mampu memengaruhi dan memobilisasi pengguna media sosial lainnya untuk ikut terlibat. Kreativitas Kaum Muda di jejaring media sosial Twitter dinilai sebagai perilaku dinamis, di mana Kaum Muda juga ingin dipandang sebagai bagian dari setiap wacana politik yang berkembang.

Substansi dari hasil penelitian ini menunjukkan bahwa penggunaan media sosial memiliki efek positif terhadap minat politik Kaum Muda dalam memerangi kasus korupsi di Indonesia. Sejalan dengan itu, kontribusi penelitian ini mempunyai rekomendasi terkait penggunaan konsep baru dalam mengampanyekan isu-isu antikorupsi di Indonesia dengan memaksimalkan penggunaan media sosial seperti Twitter. Kampanye tersebut dapat dilakukan dengan pendekatan yang lebih kreatif serta didukung dengan adanya keterampilan dalam memainkan platform media sosial. Kreativitas dan keterampilan tersebut juga sangat bergantung pada pengguna media sosial dalam memahami pesan, informasi, dan wacana politik yang berkembang. 


\section{Daftar Pustaka}

Arniawati, N., \& Sutrisno, I. (2015). Kajian Komunikasi Pemasaran Badan Pengelola Desa WisataA Bobung Dalam Meningkatkan Jumlah Wisatawan. 13(April), 96-108. http://jurnal.upnyk.ac.id/ index.php/komunikasi/article/view/1452

Bennett, S., Maton, K., \& Kervin, L. (2008). The "digital natives" debate: A critical review of the evidence. British Journal of Educational Technology, 39(5), 775-786. https://doi. $\operatorname{org} / 10.1111 / \mathrm{j} .1467-8535.2007 .00793 . x$

Beskow, D. M., Kumar, S., \& Carley, K. M. (2020). The evolution of political memes: Detecting and characterizing internet memes with multi-modal deep learning. Information Processing \& Management, 57(2), 102170. Cho, J., Ahmed, S., Keum, H., Choi, Y. J., \& Lee, J. H. (2018). Influencing myself: Self-reinforcement through online political expression. Communication Research, 45(1), 83-111.

Dahl,V.,Amnå,E.,Banaji,S.,Landberg, M., Šerek, J., Ribeiro, N. \& Zani, B. (2018). Apathy or alienation? Political passivity among youths across eight European Union countries. European Journal of Developmental Psychology, 15(3), 284-301. https://doi. org/10.1080/17405629.2017.1404985

Dávid-Barrett, E., \& Fazekas, M. (2020). Anticorruption in aid-funded procurement: Is corruption reduced or merely displaced? World Development, 132.https://doi. org/10.1016/j.worlddev.2020.105000

Dzulfaroh, A. N. (2020). Selain Jiwasraya, berikut kasus korupsi terbesar di Indonesia. Retrieved from Www.Kompas. Com website: https://www.kompas. $\mathrm{com} / \mathrm{tren} / \mathrm{read} / 2020 / 01 / 17 / 070300165 /$ selain-jiwas ray a-berikut -kasus korupsi-terbesar-di-indonesia?page $=$ all

El Adawiyah, S., Hubeis, A. V., Sumarti, T., \& Susanto, D. (2020). Political Communication of Indonesian Female Regional Leaders. Jurnal ASPIKOM, 5(2), 365-372.
Ellison, N. B., Steinfield, C., \& Lampe, C. (2007). The benefits of Facebook "friends:" Social capital and college students' use of online social network sites. Journal of computermediated communication, 12(4), 1143-1168.

Escobar, A. (2015). Degrowth, postdevelopment, and transitions: a preliminary conversation. Sustainability Science, 10(3), 451-462. https://doi.org/10.1007/s11625-015-0297-5

Firmansyah, M. A., Mulyana, D., Karlinah, S., \& Sumartias, S. (2018). Kontestasi Pesan Politik dalam Kampanye Pilpres 2014 di Twitter: Dari Kultwit Hingga Twitwar. Jurnal Ilmu Komunikasi, 16(1). Fischer, E., \& Reuber, A. R. (2011). Social interaction via new social media: (How) can interactions on Twitter affect effectual thinking and behavior? Journal of Business Venturing, 26(1), 1-18. https:// doi.org/10.1016/j.jbusvent.2010.09.002

Frelians, P. P., \& Perbawaningsih, Y. (2020). Media Sosial Ruang Dayak dalam Mereduksi Stigma Kebudayaan Dayak. Jurnal Ilmu Komunikasi, 18(2), 181. https://doi.org/10.31315/jik.v18i2.3230 Gil de Zúñiga, H., Molyneux, L., \& Zheng, P. (2014). Social media, political expression, and political participation: Panel analysis of lagged and concurrent relationships. Journal of communication, 64(4), 612-634. Grundlingh, L. (2018). Memes as speech acts. Social Semiotics, 28(2), 147-168. Guinness, D., Cutrell, E., \& Morris, M. R. (2018). Caption Crawler: Enabling reusable alternative text descriptions using reverse image search. In Proceedings of the 2018 CHI Conference on Human Factors in Computing Systems, 1-11. https://doi.org/10.1145/3173574.3174092

Hangi, R. (2018). The role of civil society organizations in fighting corruption in Entebbe Municipality: A case study of Entebbe Foundation against corruption (Doctoral dissertation, Nkumba University). 
Hansen, M. B. N. (2004). New Philosophy for New Media. Mit Press. Hasfi, N., Usmand, S., \& Santoso, H. P. (2017). Anonimitas di Media Sosial: Sarana Kebebasan Berekspresi atau Patologi Demokrasi? Jurnal Ilmu Komunikasi, 15(1), 28. https://doi.org/10.31315/jik.v15i1.2152 Holmes, K., Balnaves, M., \& Wang, Y. (2015). Red Bags and WeChat (Weixín): online collectivism during massive Chinese cultural events. Global Media Journal: Australian Edition, 9(1), 15-26.

Hsiao, Y. (2018). Understanding digital natives in contentious politics: Explaining the effect of social media on protest participation through psychological incentives. New Media and Society, 20(9), 3457-3478. https://doi.org/10.1177/1461444817749519

Hughes, D. J., Rowe, M., Batey, M., \& Lee, A. (2012). A tale of two sites: Twitter vs. Facebook and the personality predictors of social media usage. Computers in Human Behavior, 28(2), 561-569. https:// doi.org/10.1016/j.chb.2011.11.001

Hui, C. H. (1988). Measurement of individualism-collectivism. Journal of Research in Personality, 22(1), 17-36. James, C., Davis, K., Charmaraman, L., Konrath, S., Slovak, P., Weinstein, E., \& Yarosh, L. (2017). Digital life and youth well-being, social connectedness, empathy, and narcissism. Pediatrics, 140, S71-S75. https://doi.org/10.1542/peds.2016-1758F

Jati, W. R. (2016). Cyberspace, Internet, Dan Ruang Publik Baru: Aktivisme Online Politik Kelas Menengah Indonesia. Jurnal Pemikiran Sosiologi, 3(1), 25. https://doi.org/10.22146/jps.v3i1.23524

Jubba, H., Baharuddin, T., Pabbajah, M., \& Qodir, Z. (2020). Dominasi Internet di Ruang Publik: Studi Terhadap Penyebaran Wacana Gerakan Bela Islam 212 di Indonesia. AlIzzah: Jurnal Hasil-Hasil Penelitian, 15(1), 1. https://doi.org/10.31332/ai.v0i0.1631
Keating, A., \& Melis, G. (2017). Social media and youth political engagement: Preaching to the converted or providing a new voice for youth? British Journal of Politics and International Relations, 19(4), 877-894. https://doi.org/10.1177/1369148117718461

Kertamukti, R., Nugroho, H., \& Wahyono, S. B. (2019). Kontruksi ldentitas Melalui Stories Highlight Instagram Kalangan Kelas Menengah. Jurnal Aspikom, 4(1), 26-44. https://doi.org/10.24329/aspikom.v4i1.502

Khairullina, E. R., Shubovich, M. M., Bogdanova, V. I., Slepneva, E. V., Mashkin, N. A., \& Rodyukova, T. N. (2020). Modern student youth civic identity: Political activity or social responsibility? Opcion, 36(Special Edition 27), 1703-1717.

Kim, B., \& Kim, Y. (2017). College students' social media use and communication network heterogeneity: Implications for social capital and subjective well-being. Computers in Human Behavior, 73, 620-628. https://doi.org/10.1016/j.chb.2017.03.033

Kitanova, M. (2020). Youth political participation in the EU: evidence from a cross-national analysis. Journal of Youth Studies, 23(7), 819-836. https://doi. org/10.1080/13676261.2019.1636951

Kligler-Vilenchik, N., \& Literat, I. (2018). Distributed creativity as political expression: Youth responses to the 2016 U.S. presidential election in online affinity networks. Journal of Communication, 68(1), 75-97. https://doi.org/10.1093/joc/jqx005

Kossinets, G., Kleinberg, J., \& Watts, D. (2008). The Structure of Information Pathways in a SocialCommunicationNetwork. Proceedings of the ACM SIGKDD International Conference on Knowledge Discovery and Data Mining, 435-443. https://doi.org/ https://doi.org/10.1145/1401890.1401945

KPK. (2002). Komisi Pemberantasan Tindak Pidana Korupsi. (kpk.go.id). Accessed on September 21, 2020. https://www.kpk.go.id/ images/pdf/Undang-undang/uu302002.pdf 
Krauss, S. E., Zeldin, S., Abdullah, H., Ortega, A., Ali, Z., Ismail, I. A., \& Ariffin, Z. (2020). Malaysian youth associations as places for empowerment and engagement. Children and Youth Services Review, 112(March). https:// doi.org/10.1016/j.childyouth.2020.104939

Kuncoro, A. (2002). Corruption and economic growth in Indonesia. Economics and Finance in Indonesia, 79-112.

Laeli, A. N., \& Kusumaningrum, R. D. (2018). Reflection on Implementing Quotes As Attractive Media Related To Student Motivation in Learning English-Indonesian. ELLiC Proceedings, 2, 510-514. Lane,D.S., Das, V., \&Hiaeshutter-Rice, D.(2019). Civic laboratories: youth political expression in anonymous, ephemeral, geo-bounded social media. Information, Communication \& Society, 22(14), 2171-2186.

Laughland-Booÿ, J., \& Ghazarian, Z. (2020). Young People and Politics in Australia: an Introduction. Journal of Applied Youth Studies, 3(3), 189-192. https:// doi.org/10.1007/s43151-020-00025-1

Lee, D. S., Lee, K. C., \& Seo, Y. W. (2015). An analysis of shared leadership, diversity, and team creativity in an e-learning environment. Computers in Human Behavior, 42, 47-56.

Livingstone, S. (1999). New media, new audiences? New Media and Society, 1(1), 59-66. https://doi. org/10.1177/1461444899001001010

Loader, B. D., Vromen,A., \& Xenos, M.A.(2014). The networked young citizen: social media, political participation and civic engagement.

Loader, B. D., Vromen, A., \& Xenos, M. A. (2016). Performing for the young networked citizen? Celebrity politics, social networking and the political engagement of young people. Media, culture \& society, 38(3), 400-419. Lu, D., Whitehead, S., Huang, L., Ji, H., \& Chang, S. F. (2018). Entity-aware image caption generation.arXivpreprintarXiv:1804.07889.
Lutfi, A. F., Zainuri, \& Diartho, H. C. (2020). Dampak Korupsi Terhadap Pertumbuhan Ekonomi: Studi Kasus 4 Negara di ASEAN. E-Journal Ekonomi Bisnis Dan Akuntansi, 7(1), 30-35. https:// doi.org/10.19184/ejeba.v7i1.16482

Mathé, N. E. H. (2018). Engagement, passivity and detachment: 16-year-old students' conceptions of politics and the relationship between people and politics. British Educational Research Journal, 44(1), 5-24.

McFarland, D. A., \& Thomas, R. J. (2006). Bowling young: How youth voluntary associations influence adult political participation. American sociological review, 71(3), 401-425.

McQuail, D. (2011). Teori Komunikasi Massa. Retrieved from https:// difarepositories.uin-suka.ac.id/122/1/ Teori Komunikasi Masa McQuail.pdf Montessori, M. (2012). Pendidikan Antikorupsi Sebagai Pendidikan Karakter di Sekolah. Jurnal Demokrasi, 11(1). Murimi, E. K. (2018). Arresting Corruption in Africa: Role of the Youth. Murthy, D. (2012). Towards a Sociological Understanding of Social Media: Theorizing Twitter. Sociology, 46(6), 1059-1073. https://doi.org/10.1177/0038038511422553

Na,J.,Kosinski,M.,\&Stillwell,D.J.(2015).When a New Tool Is Introduced in Different Cultural Contexts: Individualism-Collectivism and Social Network on Facebook. Journal of Cross-Cultural Psychology, 46(3), 355-370. https://doi.org/10.1177/0022022114563932

Nofrima, S., Nurmandi, A., Kusuma Dewi, D., \& Salahudin. (2020). Cyber-activism on the dissemination of \#Gejayanmemanggil: Yogyakarta's student movement. Jurnal Studi Komunikasi (Indonesian Journal of Communications Studies), 4(1), 103. https://doi.org/10.25139/jsk.v4i1.2091 
O’brien, K., Selboe, E., \& Hayward, B. M. (2018). Exploring youth activism on climate change. Ecology and Society, 23(3).

Ohme, J. (2020). Mobile but Not Mobilized? Differential Gains from Mobile News Consumption for Citizens' Political Knowledge and Campaign Participation. Digital Journalism, 8(1), 103-125. https:// doi.org/10.1080/21670811.2019.1697625

Oktayusita, S. H., Suparno, B. A., \& Rochayanti, C. (2020). Reception Analysis of Millennials Generation to Ads in Social Media. Jurnal Ilmu Komunikasi, 17(2), 125-132.

O’Loughlin, B., \& Gillespie, M. (2012). Dissenting citizenship? Young people and political participation in the media-security nexus. Parliamentary Affairs, 65(1), 115-137.

Partridge,E.(2008).Fromambivalencetoactivism: young people's environmental views and actions. Youth Studies Australia, 27(2), 18.

Passini, S. (2012). The facebook and twitter revolutions: Active participation in the $21 \mathrm{st}$ century. Human Affairs, 22(3), 301-312. https://doi.org/10.2478/s13374-012-0025-0

Patra, J. I. K. (2018). Korupsi, Pertumbuhan Ekonomi Dan Kemiskinan Di Indonesia. Riset Akuntansi Dan Keuangan Indonesia, 3(1), 71-79. https:// doi.org/10.23917/reaksi.v3i1.5609

Pertiwi, K. (2019). Kesenjangan dalam Wacana Antikorupsi di Indonesia: Temuan dari Literatur Studi Korupsi Kritis. Jurnal Antikorupsi Integritas, 5(2), 133-150. Phillips, M., \& Lu, J. (2018). A quick look at NVivo. Journal of Electronic Resources Librarianship, 30(2), 104-106.

Pittman, M., \& Reich, B. (2016). Social media and loneliness: Why an Instagram picture may be worth more than a thousand Twitter words. Computers in Human Behavior, 62, 155-167.

Pope, J. (2000), Confronting Corruption: The Elements of a National Integrity System (The TI Source Book), Transparency International, Berlin and London.
Pujiyono, \& Riyanta, S. (2020). Corporate criminal liability in the collapse of bank century in Indonesia. Humanities and Social Sciences Letters, 8(1), 1-11. https:// doi.org/10.18488/journal.73.2020.81.1.11

Purbey, S., Lahor, A., Kulkarni, A., Walunjkar, C., \& Shahapurkar, A. (2017). Review Paper on Ranking of Images Based on Caption on Social Media. International Research Journal of Engineering and Technology, 4(4), 3401-3403.

Puspitasari, K. (2020). Kapabilitas dan Kepemimpinan Anies Baswedan dalam Penanganan Banjir Jakarta di Detik.com dan Kompas.com.JurnalImuKomunikasi,18(2), 221. https://doi.org/10.31315/jik.v18i2.3505

Puspitasari, L., \& Ishii, K. (2016). Digital divides and mobile Internet in Indonesia: Impact of smartphones. Telematics and Informatics, 33(2), 472-483. https:// doi.org/10.1016/j.tele.2015.11.001

Putri,W.O., \&Arifin, R.(2019).Penegakanhukum terhadap anggotalegislatifdalamkasustindak pidana korupsi di Indonesia. Jurnal Hukum Pidana Dan Ketatanegaraan, 8(1), 1-15. Rabi'e, M., \& Nurhidayati, S. (2018). Pengembangan Model Pengembangan Model Pembangunan Budaya Antikorupsi Berbasis Keluarga di Kelurahan Prenggan, Kota Yogyakarta. Integritas, 4(1), 26. https://doi.org/10.32697/integritas.v4i1.151

Ratnasari, E., Sumartias, S., \& Romli, R. (2020). Penggunaan Message Appeals dalam Strategi Pesan Kampanye Anti Kekerasan Berbasis Gender Online. Jurnal Ilmu Komunikasi, 18(3), 352. https://doi.org/10.31315/jik.v18i3.3844

Ratten, V. (2017). Social media innovations and creativity. In Revolution of innovation management (pp. 199220). Palgrave Macmillan, London. Rauschnabel, P. A., Sheldon, P., \& Herzfeldt, E. (2019). What motivates users to hashtag on social media?. Psychology \& Marketing, 36(5), 473-488. 
Reinikka, R., \& Svensson, J. (2005). Fighting corruption to improve schooling: Evidence from a newspaper campaign in Uganda. Journal of the European economic association, 3(2-3), 259-267.

Rentschler, C. A. (2017). Bystander intervention, feminist hashtag activism, and the anti-carceral politics of care. Feminist media studies, 17(4), 565-584.

Rimšaitè, L. (2019). Corruption risk mitigation in energy sector: Issues and challenges. Energy Policy, 125, 260-266.

Sagiyanto, A., \& Ardiyanti, N. (2018). Self Disclosure Melalui Media Sosial Instagram (Studi Kasus Pada Anggota Galeri Quote). Nyimak Journal of Communication, 2(1), 81-94. https:// doi.org/10.31000/nyimak.v2i1.687

Salahudin, S., Nurmandi, A., \& Loilatu, M. J. (2020). How to Design Qualitative Research with NVivo 12 Plus for Local Government Corruption Issues in Indonesia? Jurnal Studi Pemerintahan, 11(3), 469-498. https://doi.org/10.18196/jgp.113124

Sari, A. G. (2020). Fraud Auditing Law Implications in the Case of Jiwasraya Insurance in Indonesia. International Journal of Business, Economics and Management, 7(4), 203-210. https://doi. org/10.18488/journal.62.2020.74.203.210

Saroh, Y. (2016). Kampanye Antikorupsi Kekinian oleh Generasi Muda. Retrieved from youthproactive.com website: https://youthproactive.com/201603/ speak-up/kampanye-antikorupsikekinian-oleh-generasi-muda/

Saud, M., Ida, R., \& Mashud, M. (2020). Democratic practices and youth in political participation: a doctoral study. International Journal of Adolescence and Youth, 25(1), 800-808. https://doi. org/10.1080/02673843.2020.1746676
Setiadi, W. (2018). Korupsi Di Indonesia (Penyebab, Bahaya, Hambatan dan Upaya Pemberantasan, Serta Regulasi). Jurnal Legislasi Indonesia, 15(3), 249-262. Skoric, M. M., \& Poor, N. (2013). Youth engagement in Singapore: The interplay of social and traditional media. Journal of Broadcasting \& Electronic Media, 57(2), 187-204.

Sloam, J. (2014). New voice, less equal: The civic and political engagement of young people in the United States and Europe. Comparative Political Studies, 47(5), 663-688.

Sloam,J.(2016). Diversity and voice: The political participation of young people in the European Union. The British Journal of Politics and International Relations, 18(3), 521-537.

Smith, E. E., Kahlke, R., \& Judd, T. (2020). Not justdigitalnatives:Integrating technologies in professional education contexts. Australasian Journal of Educational Technology, 36(3), 1-14. https://doi.org/10.14742/ajet.5689

Sobkowicz, P., Kaschesky, M., \& Bouchard, G. (2012). Opinion mining in social media: Modeling, simulating, and forecasting political opinions in the web. Government Information Quarterly, 29(4), 470-479. https://doi.org/10.1016/j.giq.2012.06.005

Sosiawan, E. A. (2020). Penggunaan situs jejaring sosial sebagai media interaksi dan komunikasi di kalangan mahasiswa. Jurnal Ilmu Komunikasi, 9(1), 60-75. Sosiawan, E. A., \& Wibowo, R. (2019). Model dan Pola Computer Mediated Communication Pengguna Remaja Instagram dan Pembentukan Budaya Visual. Jurnal Ilmu Komunikasi, 16(2), 147. https://doi.org/10.31315/jik.v16i2.2698

Stitzlein, S. M. (2015). Teaching for dissent: Citizenship education and political activism. Routledge. Susanto, E. H. (2017). Media Sosial Sebagai Pendukung Jaringan Komunikasi Politik. Jurnal Aspikom, 3(3), 379-398. https:// doi.org/10.24329/aspikom.v3i3.123 
Syahputra, I. (2017). Demokrasi Virtual Dan Perang Siber Di Media Sosial: Perspektif Netizen Indonesia. Jurnal ASPIKOM, 3(3), 457. https://doi. org/ $10.24329 /$ aspikom.v3i3.141

Takau, N. A. W. (2020). Pengaruh Gambar dan Profil Instagram Terasrumahmu terhadap Kesadaran Merek. Jurnal Ilmu Komunikasi, 18(1), 1-17.

Talib, S. (2018). Social media pedagogy: Applying an interdisciplinary approach to teach multimodal critical digital literacy. E-Learning and Digital Media, 15(2), 55-66. https://doi.org/10.1177/2042753018756904

Urien, J. (2012). The impact of corruption on the socio- economic development of nigeria. Department of Political Science, Delta State University, Abraka - Nigeria, 2(3), 143-152. Valenzuela, S., Arriagada, A., \& Scherman, A. (2014). Facebook, Twitter, and youth engagement: A quasi-experimental study of social media use and protest behavior using propensity score matching. International Journal of Communication, 8, 25. Velasquez, A., \& Rojas, H. (2017). Political expression on social media: The role of communication competence and expected outcomes. Social Media+ Society, 3(1), 2056305117696521.

Wibowo, K. A., \& Mirawati, I. (2013). Realitas Politik Indonesia Dalam "Kacamata" Pengguna Twitter. Jurnal Kajian Komunikasi, 1(1), 11-17. https://doi.org/10.24198/jkk.vol1n1.2 Widodo, S. (2019). Membangun Pendidikan Antikorupsi di Sekolah Dasar. Jurnal Pendidikan Dasar, 10(1), 35-44. https:// doi.org/doi.org/10.21009/JPD.010.04

Wirawan, I. G. M. A. S., \& Yuliartini, ni putu rai. (2018). Ekspresi Politik Generasi Millenial Pada Pilgub Bali Tahun 2018. Prosiding Seminar Nasional Hukum Dan Ilmu Sosial, 2, 170-182. Xenos, M., Vromen, A., \& Loader, B. D. (2014). The great equalizer? Patterns of social media use and youth political engagement in three advanced democracies. Information, Communication \& Society, 17(2), 151-167. Young, J. A., Mcleod, D. A., \& Brady, S. R. (2018). The Ethics Challenge: 21st Century Social Work Education, Social Media, and Digital Literacies. Journal of Social Work Values \& Ethics The Journal of Social Work Values and Ethics, 15(1), 1-22. 